MINDFULNESS IN PRACTICE

\section{We Croak: a Return to Joy}

\author{
Doreen Schweizer ${ }^{1}$
}

Published online: 12 November 2019

(C) Springer Science+Business Media, LLC, part of Springer Nature 2019

In a March 14, 2018, interview on the "10\% Happier Podcast," Hansa Bergwall talked with Dan Harris about the new cell phone application that he and a friend created. The App is designed to send out a reminder notice five times a day. If you purchase and install it for $\$ 0.99$, a box will periodically pop up on your cell phone screen saying, "Remember, you are going to die." You have the option to click on the box for a quote from one of many different traditions on the subject of dying. Here is a sample quote from the App:

If I take death into my life, acknowledge it and face it squarely,

I will free myself from the anxiety of death and the pettiness of life -

And only then will I be free...

$$
\text { Martin Heidegger [WECROAK App] }
$$

A young man, whose own mother died suddenly when he was 11, Hansa created this App, which is called "WECROAK," partially in response to his own coming to peace with the pain and the reality of his mom's death and with the fact that death can come to anyone of us at any time - even if we are not at all expecting it. We are all far more vulnerable in this respect than we realize. In his quest to make sense of this uncertainty, and, thereby, to be more prepared for this eventuality than his own family had been, Hansa learned that most religious traditions advocate some form of regular contemplation of death on a daily basis. He could see the value of such practices, not just because they can prepare us for the inevitable loss of loved ones, but also because - worked with regularly over timethey loosen the grip of the conscious and unconscious fear of our own death that can so limit our capacity to be courageously alive in the present moment.

\section{Doreen Schweizer}

1 Lebanon, USA
With the help of a tech-savvy friend, Hansa Bergwall decided to find a way to bring the practice of death contemplation to modern day technology. He designed a computer application. The project tied in well with the fact that he and his friends had become increasingly aware of how much their cell phones were dictating their behavior. He thought perhaps the creation of the app would be one way to take back control and transform his cell phone into a useful tool instead of a mindless distraction.

As I listened to his story, I realized this was a brilliant idea. I'd already been practicing with several regular meditative contemplations on my own death, using some of the traditional Buddhist practices (Maranasati), and I had been directly experiencing their value. I knew this five-times-daily reminder would bring the awareness of my own death even more immediately into my everyday life. I downloaded the App immediately.

The morning after the WECROAK App was installed, I was meditating in a space near enough to my desk, where the cell phone was charging, for me to hear the reminder notice sound for the first time. I felt a chill go through my body, a kind of frisson. This was, in part, a general startle response to the digital sound at that quiet hour but since I had no other reminders set up on my phone, I knew what this was reminding me of, and it was eerie. My visceral reaction continued whenever I heard the sound, but only for a short time. It quickly diminished and soon was gone almost completely. The reminder became more commonplace: I heard the signal, saw the message, and sometimes - though by no means always - clicked to read the quote. Some of the passages were wonderful, some much less so. Life with the App went on with this heightened interest for a while.

The next stage in my relationship to the WECROAK reminder was that I began to be annoyed at it. It was often irksome to hear the sound when I was busily involved in a project. It was becoming an interruption. I could occasionally hear the thought in my mind, "Yes, I know this already;" or, "Okay, enough already." I did sort of see some of the irony in 
this line of my thinking. At one point, I smiled as I recalled Emily Dickinson's poem with the line,

Because I could not stop for deathHe kindly stopped for me...

Even so, the random appearance of the five-daily reminder messages did continue to annoy me for a while, but gradually over several months, WECROAK settled in and played a softer role in my life. It became a friendly, constant, and dependable companion, who would at any moment whisper matter-of-factly into my ear, "Don't forget, you are going to die." Miraculously, modern technology allows it to have a built-in kindness: it never goes off during the hours of sleep, only when I am awake. By the time September rolled around, I'd had the App for over six months, and we had a congenial relationship, with just a touch of distant tolerance on my part. We were about to become more intimate.

On September 3, Labor Day evening, 2018, I was swimming with a friend at Mascoma Lake. The surprise of a sudden rainstorm ended our final swim of the summer. My friend had driven there and left by car, but I had biked. The rain let up some, and I started out alone on the seven-mile trip home on the wet, gravelly bike path. I was moving quickly, racing the next storm, and was about a third of the way home when the bicycle skidded. I hit the ground hard-left shoulder first, helmeted head second, hips and legs third. I knew I was injured, but I was able to slide out from my entanglement with the bike and roll onto my back. Once there, I found I could not move much. It was getting to be dusk; the ground was wet; and I had a wet bathing suit under my shirt and jeans. Fortunately, my cell phone was in my right hand pocket.

I sent a text, but got a message back saying it had not gone through. I called 911, but only managed to get my name and some partial information about the what-and-where of my situation when the call dropped. I realized I was on the edge of cell phone service, but WECROAK did not apparently need cell phone service to operate. Shortly after my first call dropped and a second attempt failed completely, the reminder notice went off. I did not look at the screen. I knew what it said.

My first response was to smile. Then I felt a bit comforted: I thought, "Yes, right, things could be much worse." This was followed by another reflection, "Oh, I get it. Death could be like this: cold and dark and wet; alone with night falling; on a deserted bike path; no help in sight; no one knowing what was happening to me." Within an instant, I realized that, in fact, this could be it right here and now. Death could be, not just like this - this could actually be my death. It was almost nightfall and drizzling again. Probably no one would come along this section of the path until the morning. My body was already shaking from shock and the cold.

Shortly after I had crashed to the ground, I had begun a focused-awareness meditation that I know well in order to steady my mind and calm my heart. With the arrival of the WECRAOK reminder message, I switched my practice to one of the more formal Maranasati (death awareness) practices of early Buddhism, a very simple one that I had learned in studying with Bhikkhu Anālayo (see https://dharmaseed.org/ teacher/439/). I focused on the in and out breath. With each arising inhale, I concentrated on the fact that this one could be my last breath. On each exhale, I let go completely-fully relaxing both body and mind. I "let the mind rest on the body, just as the body rests on the cushion." Within that practice, I found the total absence of pain.

I did not die. Help came in the form of two police cruisers, an ambulance with two EMT's, and the dear friend I had texted-my message to her had gotten through. I was taken to the hospital. The possibility of this being the last in-breath came with me, as did my cell phone with both its wonderful ability to connect me to the support I needed and its WECROAK App giving steady and regular reassurance that I will indeed die.

If I am killed, I can die but once;

But to live in constant dread of it,

Is to die over and over again.

Abraham Lincoln [WECROAK App]

Through that Labor Day night in the hospital, I had a lot of $\mathrm{x}$-rays and a couple of CT scans. I was diagnosed with a broken collarbone, two broken ribs, and three pelvic fractures. Being moved onto and off the tables and gurneys for the various tests hurts a lot. It took four people-each one supporting an arm or a leg and part of my torso - to manage the transitions in a way that kept the pain at a bearable level. I could not eat for almost twenty-four hours because I might have needed surgery. Fortunately, I did not but by the time I had been allowed a roll and some soup, I had not slept in almost forty-eight hours and was exhausted. I was lucky that I could again find the complete absence of pain in the stillness of full mental and physical letting go into the outbreath.

As evening came, I settled into such a deep sleep that I was even able to stay close to it when the nurse came in to check my vital signs. She spoke to me, and I roused a bit but did not even open my eyes as she explained that they wanted to start me on Lovanox. I knew of this drug, it is an anticoagulant medication, which is administered by a shot in the abdomen. It is often given to people on bed rest to prevent blood clots. It made some sense given my condition, but I remembered that it had once caused an internal bleed in my mother, which almost resulted in her death. I told the nurse that I wanted to think about it before agreeing to take it. I said I'd consider it in the morning - not now - and let her know my decision then. She easily agreed and left the room. I was falling back into my pleasant sleep when someone else entered. Again, I did not open my eyes as a doctor identified himself and spoke to me. 
You may remember that the WECROAK App does not send reminder messages at night. You may also remember that it did not seem to need a strong cell signal to function. Apparently, sometimes it does not even need a cell phone. The faceless doctor was close to my ear when he said, "You have to take the Lovanox. If you don't, you could die. You could throw a blot clot, which will quickly go to your heart, and you will die. Quickly. So quickly that we will not be able to intervene." I do not know if he saw the smile on my face. He said again, "You will die." I said in a friendly manner, "I know." I paused, then said quietly, "I will think about the Lovanox in the morning and let you know what I decide." He left and I went back to sleep.

In the morning, the kind nurse told me she had checked with her charge nurse after that episode in the night. They both agreed the doctor had been out of line and also a bit incorrect in the information he conveyed. It really did not matter to me, though her behavior added to my growing conviction that everyone I was encountering was a compassionate person and was caring for me in the way they thought best —including the late night WECROAK doctor. Perhaps some of their ways were strange and felt less familiar, unkind even, while the caring styles of others were more comfortable and felt good. My job there was not to critique them but to befriend them and appreciate all their efforts. At the same time, I knew I must courageously navigate my own path to healing. I knew I needed both to be the center of my own care, and to accept and rejoice in the help and love offered by the professionals around me. A delicate balance had to be lived moment by moment.

Analysis of death is not for the sake of becoming fearful but to appreciate this precious lifetime. Dalai Lama [WECROAK App]
I kept the cell phone nearby through those two and a half days in hospital, the ten days in rehab, the two months home alone under the care of home health services, and beyond. WECROAK and several other death awareness practices have been very important in every step of the way. They helped me to relax and keep my energy fresh and alive. They helped me to know that I could ask to have my hospital bed turned to face the window and the gardens, instead of the TV. They helped me to appreciate the monarch butterflies on the late summer Echinacea in that garden, the sunrise over the distant hills, the nurses' and aides' stories about working in a prison, teaching in Africa, raising horses, taking care of elderly parents and young children between work shifts. An awareness of death helped me to fully benefit from and enjoy the wonderful skills of PT's and OT's, as well as the strong, steady love offered by my community - the good food they brought, the rides they gave, the conversations. The powerful nourishment of friendship and care was enhanced by death. "In Bhutan, they say contemplating death five times daily brings happiness" [WECROAK App; Home Page].

I know for sure that the soft, steady closeness of my own death quickly facilitated my return to joy, again and again. My recollections of the naturalness and inevitability of death contributed greatly to my resiliency in adapting to the sudden and radically changed life circumstances I found myself in on the day after Labor Day. They played an important part in my healing from the physical and mental trauma caused by the bicycle accident. I continue to practice with them.

Publisher's Note Springer Nature remains neutral with regard to jurisdictional claims in published maps and institutional affiliations. 